\title{
Excessive screen time is associated with emotional lability in preschool children
}

\author{
Ayse Oflu, M.D., Assistant Professor ${ }^{a}$, Ozlem Tezol, M.D., Assistant Professor ${ }^{b}$, \\ Songul Yalcin, M.D., PhD, Professor' ${ }^{c}$, Deniz Yildiz, M.D. ${ }^{d}$, Nilgun Caylan, M.D. ${ }^{e}$, \\ Dilsad F. Ozdemir, M.D., Professorf, Seyma Cicek, M.D. ${ }^{g}$ and Meryem E. Nergiz, M.D. ${ }^{h}$
}

a. Department of Pediatrics, Afyonkarahisar Health Sciences University, Faculty of Medicine, Afyonkarahisar.

b. Department of Pediatrics, Mersin University, Faculty of Medicine, Mersin.

c. Department of Pediatrics, Hacettepe University, Faculty of Medicine; Ankara.

d. Department of Pediatrics, Dr. Sami Ulus Child Hospital, Ankara.

e. Department of Child and Adolescents Health, Ministry of Health, Ankara.

f. Department of Child and Adolescents Psychiatry, Hacettepe University, Faculty of Medicine, Ankara.

g. Department of Pediatrics, Etimesgut Sehit Sait Ertürk Hospital, Ankara.

h. Department of Pediatrics, Yildırım Beyazıt University, Yenimahalle Research Hospital, Ankara.

E-mail address:

Ayse Oflu, M.D.:

ayseoflu@gmail.com

Funding:

None.

Conflict of interest:

None.

Received: 5-23-2020

Accepted: 9-11-2020

\section{ABSTRACT}

Introduction. Previous studies have found that excessive screen time or early screen exposure is associated with poor attention, lack of behavioral control, delayed language and deficit in executive functions. The aim of this study was to investigate the relationship between screen time and emotion regulation skills, which is one of the important life components affecting the social relations of children aged 2 to 5 years.

Population and methods. This cross-sectional descriptive study was carried out in a university hospital between January 1, 2018 and March 1, 2018. Mothers of healthy children aged 2-5 years with a daily screen time of less than 1 hour or over 4 hours were included in the study. A structured survey and the Emotion Regulation Checklist for parents were applied to the mothers who agreed to participate.

Results. Of 240 children participating in the study, $98(40.8 \%)$ had $\geq 4$ hours of screen time. Caring by mother, age at first screen exposure 12 months and older, notco-viewing with parents were found to be associated with $\geq 4$ hours of screen time $(p=0.002, p=0.002, p=0.012$, respectively). The ratio of participants with highlability / negativity (L/N) score was significantly higher in children with screen time of $\geq 4$ hours and not co-viewing with parents $(p=0.004$, $p=0.033$, respectively).

Conclusions. This study investigating the relationship between the emotion regulation skill and screen time revealed that excessive screen time is associated with emotional lability in this early childhood period.

Key words: emotional regulation, screen time, child.

http:/ / dx.doi.org/10.5546/ aap.2021.eng.106

To cite: Oflu A, Tezol O, Yalcin S, Yildiz D, et al. Excessive screen time is associated with emotional lability in preschool children. Arch Argent Pediatr 2021;119(2):106-113.

\section{INTRODUCTION}

In recent years, there has been a marked increase in media diversity and usage. Traditional (television) and new media (mobile phones, smartphones, tablets, and social media) have come to dominate the lives and leisure time of many children. ${ }^{1}$ This diversity and increase use of media has also affected the pre-schoolers. Now for pre-schoolers, screen time not only includes watching television, but also the use of computers and mobile devices with touchscreen. ${ }^{2}$ According to the American Academy of Pediatrics (AAP) guidelines, children below the age of two years should not have any screen exposure, and screen time of $\geq 1$ hour per day is defined as excessive among children aged 2-5 years. In addition the use of digital media should be restricted for children while eating or one hour before sleeping, in order to grow and develop properly. ${ }^{3}$ Nowadays, the American Academy of Pediatrics released new recommendations for media habits during COVID-19 pandemic, setting a structured daily routine for children and teens, limiting screen entertainment. A greater allowance is often warranted for screen entertainment during the COVID-19 crisis but it is also recommended not to take up the majority of any child's waking hours or interfere with sleep. ${ }^{4}$

The results of previous researches on the effect of screen time on cognitive processes vary in preschool children. Excessive screen time or early screen exposure is associated with poor attention, lack of behavioural control, delayed 
language and deficits in executive functions. ${ }^{5}$ Excessive screen use is also reported to result in neuroanatomical changes which are related to decreased empathy, poor impulse control, and emotional processing. ${ }^{6}$ Some studies have shown that screen time is not a strong predictor of problems in these cognitive skills. ${ }^{7}$ It has been reported that beginning at about 2 years, well-designed, age-appropriatle TV programs with specific educational goals can provide an additional route to early language and literacy for children. Quality programs also promote cognitive development aspects, including positive racial attitudes and creative play. ${ }^{8}$

Emotional regulation (ER) is defined as the extrinsic and intrinsic processes responsible for monitoring, evaluating, and modifying emotional reactions. ER covers the management and organization of various systems and components, such as the internal systems, social and behavioral components. ${ }^{9}$ ER supplies more adaptive strategic behaviors and encourages appropriate and flexible responses in different emotional contexts. ${ }^{10}$ Emotional regulation has a gradual development over time with a series of skills gained following birth. ${ }^{11}$ This developmental process involves neurobiological development (development of the frontal lobe), conceptual development (understanding emotional processes) and socializing skills. It is very important as a process in which individual differences in emotional regulation skills of adults develop. Children interact more with the outside world, and social contexts expand in the preschool period. During this period, children become more skilled in terms of emotional regulation as they realize that there are possibilities of approaching, moving away or changing emotions that may attract emotional attention. ${ }^{12}$

Considering the importance of social interactions in gaining the ability of ER, the purpose of this study is to examine the associations between screen time and ER of children aged 2 to 5 years.

\section{MATERIAL AND METHODS}

\section{Study design}

This, study was designed as a cross-sectional descriptive study and carried out in a university hospital between January 1, 2018 and March 1, 2018. Mothers of healthy children aged $2-5$ years with a daily screen time of less than 1 hour or over 4 hours were included in the study. Children having a history of prematurity and insufficient birth weight, not breastfed at all, those with a delay in language development and having chronic physical and psychiatric illness were excluded. The reason for determining these exclusion criteria was to exclude the effect of resume features that could cause behavioural problems. A structured survey and the Emotion Regulation Checklist (ERC) for parents were applied to the mothers who agreed to participate.

Permission to carry out the study was approved by the local ethics committee. All study procedures were performed in accordance with the Declaration of Helsinki.

\section{Data collection}

The number of mothers who applied to pediatric outpatient clinic, was calculated as 1570 / month, based on previous months' records. In Turkey, the ratio of children using screens for over four hours was found to be as $19.7 \%$ in a previous multicenter study. ${ }^{13}$ Accompanied by these datas, the minimum sample size was calculated as 226 with a $95 \%$ confidence interval using 'OpenEpi (https: / / www.openepi.com/ SampleSize/SSPropor. Htm) calculator' according to $\mathrm{n}=\left[\operatorname{DEFF}^{*} \mathrm{~Np}(1-\mathrm{p})\right] /\left[\left(\mathrm{d}^{2} / \mathrm{Z}^{2}{ }_{1-\alpha / 2}{ }^{*}(\mathrm{~N}-1)+\mathrm{p}^{*}(1-\mathrm{p})\right]\right.$ equation. The parameters were sustained as population size $(\mathrm{N}): 3140, \%$ frequency of $(\mathrm{p})$ : $19.7 \%+/-5$, confidence limits as $\%(d): 5 \%$.

As in other studies ${ }^{14}$ only mother-child couples were included in this study. The potential bias would be negligible because more reliable and accurate information about children could be obtained from mothers; secondly, children were mostly brought to the hospital by mothers in this region. Since the hospital where the study was conducted is a health institution that people of all sociocultural levels apply, the representative power of the sample was accepted to be sufficient. The mother-child couple waiting in the waiting room before the examination were informed about the content and purpose of the study, consent was obtained, but they were not informed about the ideal screen time. Then, mothers were asked to fill a structured survey and ERC. The surveys and scales were collected during the examination. Counseling was made at the points where problems were detected and monitoring was planned.

\section{Structured survey}

The structured paper survey consisted of twenty-four questions that were fulfilled by the mothers. Age, gender, parental ages and 
educational levels, mother's working status, family structure, number of children in the family, family type, caregiver of the child (mother or else), the income level were questioned as sociodemographic data. Participants were grouped according to daily screen time as low ( $\leq 1 \mathrm{~h} /$ day) or high ( $\geq 4 \mathrm{~h} /$ day). Child's first age of exposure to the screen, co-viewing with parents, reacting to the limitation of the screen time, delaying daily needs was also questioned.

\section{Emotion Regulation Checklist (ERC)}

ERC was developed in 1997 by Shields and Cicchetti. ${ }^{15}$ The validity, reliability, and adaptation of the scale for Turkish children were studied by Batum in 2007. ${ }^{16}$ The ERC can be answered by adults who know the child well, such as a father, mother or caregiver. The ERC contains 24 items that are assessed on a four-point Likert scale ( $1=$ never; 2 = sometimes; $3=$ often; 4 = almost always). The ERC includes two subscales: lability/negativity subscale (L/N-S) and Emotion Regulation subscale (ER-S). ER-S consists of 10 items to elicit the child's emotional self-awareness and constructive emotional expressiveness; and the L/N-S consist of 13 items that measure lack of flexibility, emotional activation, reactivity, anger dysregulation, and mood lability. The internal consistency of both subscales has been shown to be adequate $(\mathrm{L} / \mathrm{N}$ $\alpha=0.96$; ER $\alpha=0.83$ ). High scores from the scale indicate that the child has a high level of emotion regulation skills.

\section{Statistical analysis}

Descriptive statistics were presented as numbers and percentages for categorical data. The $\chi^{2}$ test was used to compare the frequencies of categorical variables. Multivariate logistic regression analysis was performed to determine the factors associated with screen time of children after adjusting for the gender, maternal education, paternal education, maternal occupation, caregiver, number of children, birth order, age at first screen exposure, co-viewing with parents. Adjusted ORs were calculated at $95 \%$ confidence intervals. The total ERC score, ER score and L/N scores were were divided into quartiles and ratio of participents having the highest quartiles were used in the analyse for comparison. The level of statistical significance was set at $\mathrm{P}<0.05$. Statistical analysis was performed with SPSS version 22.0 (IBM Corp., Armonk, NY, USA).

\section{RESULTS}

Of the 240 children participating in the study, $98(40.8 \%)$ had $\geq 4$ hours of screen time. Table 1 shows the associations between sociodemographic factors and screen time. Logistic regression analysis on factors associated with screen time of children are shown in Table 2. Caring by mother; age at first screen exposure 12 months and older; not co-viewing with parents were found to be associated with $\geq 4$ hours of screen time.

Associations between socio-demographic characteristics and participants with high-ERC scores are given in Table 3. Table 4 shows the associaitons between screen time characteristics and high-ERC scores. The ratio of participants with high-L / N score was significantly higher in children with screen time of $\geq 4$ hours and not co-viewing with parents $(p=0.004, p=0.033$, respectively).

\section{DİSCUSSİON}

Progress in information and communication technologies has increased the use of technological devices. This increase made it easier for preschool children to get acquainted with devices such as tablets and smartphones before acquiring basic skills. ${ }^{17}$ The present study, in order to reveal the possible effects of the screen exposure, compared the groups with the least screen time and those that were far above the recommended screen time.

Spending time on screen and interacting with a screen rather than parents or other humans may reduce the amount of time in which children can practice their ability to recognize emotions in others, experience the emotions of interacting with others. Skalická et al., ${ }^{18}$ suggested that extended screen time exposure might impair young child's socialization processes and result in a lower ability to understand emotions. ER is conceptualized as the emotional modulation ability that enables the person to establish the most appropriate relationship with the environment. It is critical both in initiating, motivating, and organizing adaptive behavior, and need for the prevention of stressful levels of negative emotions. Emotion lability/negativity is described as child's rapidity in responding to emotion eliciting stimuli and simultaneous difficulty in recovering from negative emotional reactions. ${ }^{19}$ Children with higher emotion lability / negativity were reported to show lower levels of competent social functioning. ${ }^{20}$ Furthermore, 
TABLE 1. Relations of sociodemographic factors with screen time of children*

\begin{tabular}{|c|c|c|c|c|}
\hline & & \multicolumn{2}{|c|}{ Screen time } & \multirow[b]{2}{*}{$p$} \\
\hline & & $\begin{array}{c}\leq 1 \text { hours } \\
\mathrm{n}=142(58.2 \%)\end{array}$ & $\begin{array}{c}\geq 4 \text { hours } \\
\mathrm{n}=98(40.8 \%)\end{array}$ & \\
\hline Age & $\begin{array}{l}<48 \text { months } \\
\geq 48 \text { months }\end{array}$ & $\begin{array}{l}95(63.3 \%) \\
47(52.2 \%)\end{array}$ & $\begin{array}{l}55(36.7 \%) \\
43(47.8 \%)\end{array}$ & 0.090 \\
\hline Gender & $\begin{array}{l}\text { Female } \\
\text { Male }\end{array}$ & $\begin{array}{l}78(66.1 \%) \\
64(52.5 \%)\end{array}$ & $\begin{array}{l}40(33.9 \%) \\
58(47.5 \%)\end{array}$ & 0.032 \\
\hline Maternal age, mean \pm SD & Years & $31.8 \pm 5.0$ & $32.1 \pm 5.3$ & 0.865 \\
\hline Paternal age, mean \pm SD & Years & $34.2 \pm 4.8$ & $35.7 \pm 6.0$ & 0.214 \\
\hline Maternal education & $\begin{array}{l}\leq \text { high school } \\
>\text { high school }\end{array}$ & $\begin{array}{l}58(46.8 \%) \\
84(72.4 \%)\end{array}$ & $\begin{array}{l}66(53.2 \%) \\
32(27.6 \%)\end{array}$ & $<0.001$ \\
\hline Paternal education & $\begin{array}{l}\leq \text { high school } \\
>\text { high school }\end{array}$ & $\begin{array}{l}63(51.6 \%) \\
79(66.9 \%)\end{array}$ & $\begin{array}{l}59(48.4 \%) \\
39(33.1 \%)\end{array}$ & 0.016 \\
\hline Maternal occupation & $\begin{array}{l}\text { Housewife } \\
\text { Working }\end{array}$ & $\begin{array}{l}61(50.0 \%) \\
81(68.6 \%)\end{array}$ & $\begin{array}{l}61(50.0 \%) \\
37(31.4 \%)\end{array}$ & 0.003 \\
\hline Caregiver & $\begin{array}{l}\text { Mother } \\
\text { Grandparents / Nursemaid } \\
\text { Nursery }\end{array}$ & $\begin{array}{l}58(46.8 \%) \\
45(66.2 \%) \\
39(81.3 \%)\end{array}$ & $\begin{array}{l}66(53.2 \%) \\
23(33.8 \%) \\
9(18.8 \%)\end{array}$ & $<0.001$ \\
\hline Number of children & $\begin{array}{l}1 \\
\geq 2\end{array}$ & $\begin{array}{l}65(71.4 \%) \\
77(51.7 \%)\end{array}$ & $\begin{array}{l}26(28.6 \%) \\
72(48.3 \%)\end{array}$ & 0.003 \\
\hline Birth order & $\begin{array}{l}1 \\
\geq 2\end{array}$ & $\begin{array}{l}88(66.7 \%) \\
54(50.0 \%\end{array}$ & $\begin{array}{l}44(33.3 \%) \\
54(50.0 \%)\end{array}$ & 0.009 \\
\hline Age at first screen exposure & $\begin{array}{l}<12 \text { months } \\
\geq 12 \text { months }\end{array}$ & $\begin{array}{c}39(45.3 \%) \\
103(66.9 \%)\end{array}$ & $\begin{array}{l}47854.7 \%) \\
51(33.1 \%)\end{array}$ & 0.001 \\
\hline Co-viewing with parents & $\begin{array}{l}\text { Yes } \\
\text { No }\end{array}$ & $\begin{array}{c}114(64.8 \%) \\
28(43.8 \%)\end{array}$ & $\begin{array}{l}62(35.2 \%) \\
36(56.3 \%)\end{array}$ & 0.003 \\
\hline
\end{tabular}

${ }^{*} \mathrm{n}(\%) /$ mean $\pm \mathrm{SD}$

TABLE 2. Logistic regression analysis on factors associated with screen time of children*

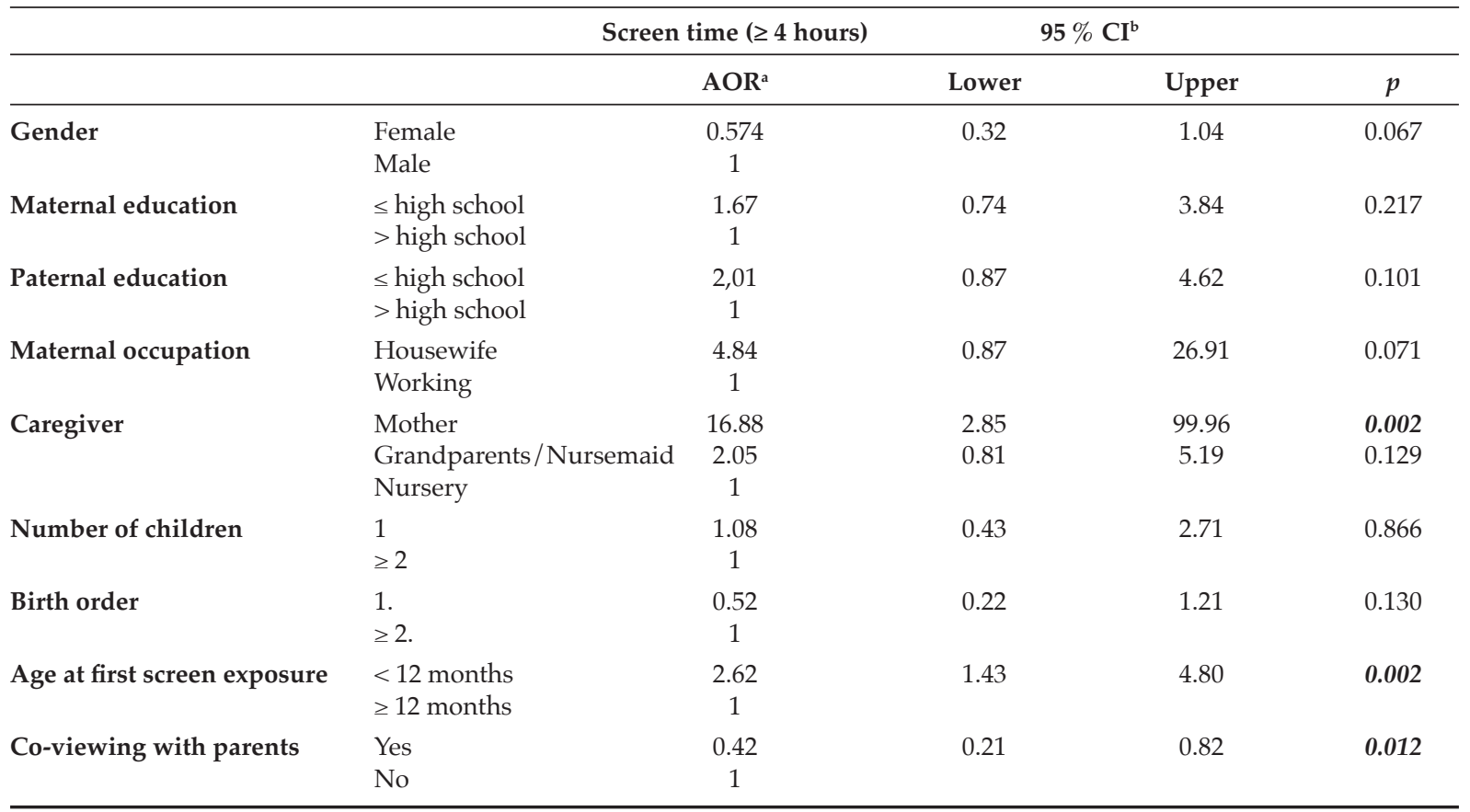

* Adjusted for gender, maternal education, paternal education, maternal occupation, caregiver, number of children, birth order, age at first screen exposure, co-viewing with parents.

** Reference category: $\leq 1$ hours.

${ }^{a}$ Adjusted Odds Ratio.

${ }^{\mathrm{b}}$ Confidence interval. 
children with high negative emotionality such as anger more inclinable to develop both internalizing and externalizing problems in childhood and youth. ${ }^{21}$

As a factor that has a place in the life of children that competes with parental behavior and whose effect is increasing day by day, the question is "To what extent does screen time affect ER?". Excessive screen time (e.g., more than 2-3 $\mathrm{h}$ exposure to electronic media) can affect the developing brain which has important consequences for cognitive and motor

TABLE 3. The association between socio-demographic characteristics and the ratio of having the highest quartiles of emotional regulation scale scores*

\begin{tabular}{|c|c|c|c|c|c|c|c|c|}
\hline & & $\begin{array}{c}\text { Total } \\
\mathbf{n}\end{array}$ & $\begin{array}{c}\text { ER Score } \\
4^{\text {th }} \text { quartile }\end{array}$ & $p$ & $\begin{array}{l}\text { L/N Score } \\
4^{\text {th }} \text { quartile }\end{array}$ & $p$ & $\begin{array}{l}\text { Total Score } \\
4^{\text {th }} \text { quartile }\end{array}$ & $p$ \\
\hline Age & $\begin{array}{l}<48 \text { months } \\
\geq 48 \text { months }\end{array}$ & $\begin{array}{c}150 \\
90\end{array}$ & $\begin{array}{l}50(33.3 \%) \\
25(27.8 \%)\end{array}$ & 0.369 & $\begin{array}{l}38(25.3 \%) \\
31(34.4 \%)\end{array}$ & 0.131 & $\begin{array}{l}45(30.0 \%) \\
18(20.0 \%)\end{array}$ & 0.088 \\
\hline Gender & $\begin{array}{l}\text { Female } \\
\text { Male }\end{array}$ & $\begin{array}{l}118 \\
122\end{array}$ & $\begin{array}{l}41(34.7 \%) \\
34(27.9 \%)\end{array}$ & 0.251 & $\begin{array}{l}29(24.6 \%) \\
40(32.8 \%)\end{array}$ & 0.160 & $\begin{array}{l}34(28.8 \%) \\
29(23.8 \%)\end{array}$ & 0.375 \\
\hline Maternal age & $\begin{array}{l}<30 \text { years } \\
\geq 30 \text { years }\end{array}$ & $\begin{array}{l}103 \\
137\end{array}$ & $\begin{array}{l}32(31.1 \%) \\
43(31.4 \%)\end{array}$ & 0.958 & $\begin{array}{l}29(28.2 \%) \\
40(29.2 \%)\end{array}$ & 0.860 & $\begin{array}{l}25(24.3 \%) \\
38(27.7 \%)\end{array}$ & 0.546 \\
\hline Paternal age & $\begin{array}{l}<30 \text { years } \\
\geq 30 \text { years }\end{array}$ & $\begin{array}{c}53 \\
187\end{array}$ & $\begin{array}{l}20(37.7 \%) \\
55(29.4 \%)\end{array}$ & 0.248 & $\begin{array}{l}14(26.4 \%) \\
55(29.4 \%)\end{array}$ & 0.670 & $\begin{array}{l}13(24.5 \%) \\
50(26.7 \%)\end{array}$ & 0.747 \\
\hline Maternal education & $\begin{array}{l}\leq \text { high school } \\
>\text { high school }\end{array}$ & $\begin{array}{c}67 \\
173\end{array}$ & $\begin{array}{l}25(37.3 \%) \\
50(28.9 \%)\end{array}$ & 0.207 & $\begin{array}{l}16(23.9 \%) \\
53(30.6 \%)\end{array}$ & 0.300 & $\begin{array}{l}21(31.3 \%) \\
42(24.3 \%)\end{array}$ & 0.264 \\
\hline Paternal education & $\begin{array}{l}\leq \text { high school } \\
>\text { high school }\end{array}$ & $\begin{array}{c}58 \\
152\end{array}$ & $\begin{array}{l}22(37.9 \%) \\
53(29.1 \%)\end{array}$ & 0.207 & $\begin{array}{l}19(32.8 \%) \\
50(27.5 \%)\end{array}$ & 0.439 & $\begin{array}{l}14(24.1 \%) \\
49(26.9 \%)\end{array}$ & 0.675 \\
\hline Maternal occupation & $\begin{array}{l}\text { Housewife } \\
\text { Working }\end{array}$ & $\begin{array}{l}122 \\
118\end{array}$ & $\begin{array}{l}36(29.5 \%) \\
39(33.1 \%)\end{array}$ & 0.554 & $\begin{array}{l}36(29.5 \%) \\
33(28.0 \%)\end{array}$ & 0.792 & $\begin{array}{l}32(26.2 \%) \\
31(26.3 \%)\end{array}$ & 0.994 \\
\hline Caregiver & $\begin{array}{l}\text { Mother } \\
\text { Grandparent/ } \\
\text { Nursemaid } \\
\text { Nursery }\end{array}$ & $\begin{array}{l}125 \\
65 \\
50\end{array}$ & $\begin{array}{l}36(28.8 \%) \\
25(38.5 \%) \\
14(28.0 \%)\end{array}$ & 0.338 & $\begin{array}{l}40(32.0 \%) \\
16(24.6 \%) \\
10(26.0 \%)\end{array}$ & 0.504 & $\begin{array}{l}31(24.8 \%) \\
18(27.7 \%) \\
14(28.0 \%)\end{array}$ & 0.867 \\
\hline Number of children & $\begin{array}{l}1 \\
\geq 2\end{array}$ & $\begin{array}{c}91 \\
149\end{array}$ & $\begin{array}{l}24(26.4 \%) \\
51(34.2 \%)\end{array}$ & 0.203 & $\begin{array}{l}22(24.2 \%) \\
47(31.5 \%)\end{array}$ & 0.221 & $\begin{array}{l}23(25.3 \%) \\
40(26.8 \%)\end{array}$ & 0.788 \\
\hline Birth order & $\begin{array}{l}1 \\
\geq 2\end{array}$ & $\begin{array}{l}132 \\
108\end{array}$ & $\begin{array}{l}39(29.5 \%) \\
36(33.3 \%)\end{array}$ & 0.529 & $\begin{array}{l}37(28.0 \%) \\
32(29.6 \%)\end{array}$ & 0.785 & $\begin{array}{l}31(23.5 \%) \\
32(29.6 \%)\end{array}$ & 0.282 \\
\hline
\end{tabular}

${ }^{*} \mathrm{n}(\%)$

TABLE 4. The association between screen time characteristics and the ratio of having the highest quartiles of emotional regulation scale scores*

\begin{tabular}{|c|c|c|c|c|c|c|c|c|}
\hline & & $\begin{array}{c}\text { Total } \\
\mathbf{n}\end{array}$ & $\begin{array}{c}\text { ER Score } \\
4^{\text {th }} \text { quartile }\end{array}$ & $p$ & $\begin{array}{l}\mathrm{L} / \mathrm{N} \text { Score } \\
4^{\text {th }} \text { quartile }\end{array}$ & $p$ & $\begin{array}{l}\text { Total Score } \\
4^{\text {th }} \text { quartile } \\
\end{array}$ & $p$ \\
\hline Screen time & $\begin{array}{l}<1 \text { hours } \\
\geq 4 \text { hours }\end{array}$ & $\begin{array}{c}142 \\
98\end{array}$ & $\begin{array}{l}50(35.2 \%) \\
25(25.5 \%)\end{array}$ & 0.111 & $\begin{array}{l}31(21.8 \%) \\
38(38.8 \%)\end{array}$ & 0.004 & $\begin{array}{l}37(26.1 \%) \\
26(26.5 \%)\end{array}$ & 0.935 \\
\hline $\begin{array}{l}\text { Age at first screen } \\
\text { exposure }\end{array}$ & $\begin{array}{l}<12 \text { months } \\
\geq 12 \text { months }\end{array}$ & $\begin{array}{c}86 \\
154\end{array}$ & $\begin{array}{l}25(29.1 \%) \\
50(32.5 \%)\end{array}$ & 0.586 & $\begin{array}{l}28(32.6 \%) \\
41(26.6 \%)\end{array}$ & 0.330 & $\begin{array}{l}23(26.7 \%) \\
40(26.0 \%)\end{array}$ & 0.897 \\
\hline $\begin{array}{l}\text { Co-viewing } \\
\text { with parents }\end{array}$ & $\begin{array}{l}\text { Yes } \\
\text { No }\end{array}$ & $\begin{array}{c}176 \\
64\end{array}$ & $\begin{array}{l}61(34.7 \%) \\
14(21.9 \%)\end{array}$ & 0.059 & $\begin{array}{l}44(25.0 \%) \\
25(39.1 \%)\end{array}$ & 0.033 & $\begin{array}{l}49(27.8 \%) \\
14(21.9 \%)\end{array}$ & 0.353 \\
\hline $\begin{array}{l}\text { Reacting to the } \\
\text { limitation of the } \\
\text { screen time }\end{array}$ & $\begin{array}{l}\text { Yes } \\
\text { No }\end{array}$ & $\begin{array}{c}93 \\
147\end{array}$ & $\begin{array}{l}25(26.9 \%) \\
50(34.0 \%)\end{array}$ & 0.246 & $\begin{array}{l}31(33.3 \%) \\
38(25.9 \%)\end{array}$ & 0.212 & $\begin{array}{l}22(23.7 \%) \\
41(27.9 \%)\end{array}$ & 0.468 \\
\hline Delaying daily needs & $\begin{array}{l}\text { Yes } \\
\text { No }\end{array}$ & $\begin{array}{l}121 \\
119\end{array}$ & $\begin{array}{l}35(28.9 \%) \\
40(33.6 \%)\end{array}$ & 0.433 & $\begin{array}{l}39(32.2 \%) \\
30(25.2 \%)\end{array}$ & 0.230 & $\begin{array}{l}29(24.0 \%) \\
34(29.6 \%)\end{array}$ & 0.418 \\
\hline
\end{tabular}


development, learning and memory, ER, and overall health. Research suggests that earlier and longer exposure to electronic media is associated with an increased risk of psychiatric symptomology, particularly those of attentional problems and hyperactivity, anxiety disorders, and depression.22 It has been aslo found that high background exposure to television in children under 5 years of age reduces the amount and quality of parent-child interaction and takes them away from play, negatively affects language use and acquisition, attention, cognitive development, and executive function. ${ }^{23}$ Existing literature with older children and adolescents put forth mixed support for the relation between screen use and well-being, with some studies showing harmful effects and others showing negligibly small and nonsignificant correlations indicating harm. There is limited knowledge of how screen time links to psychological well-being, especially in young children aged 5 years or under. ${ }^{24}$ A recent study found out that children and adolescents aged 2 to 17 years who spent more time using screen media were lower in psychological well-being than low users. High users of screens were significantly more likely to display poor emotion regulation which was not staying calm, arguing too much, being difficult to get along with. ${ }^{25}$ The present study also showed that children with excessive screen time were more labile and negative in terms of emotions. Besides, there was no relationship between ER component and screen time. AAP also recommends parents coview with their children and help them to understand what they see. ${ }^{3}$ Present study reveals the justification of this proposal in terms of emotional regulation. Because we determined that, the children who were alone in front of the screen were more emotionally labil. Therefore, given that most mothers have insufficient knowledge of proper screen usage for their children, like coviewing, it is important to question media use habits and educate them about proper use. During the pandemic, children's screen time has also changed compared to before. Even under these conditions, the importance of children's family life and physical activities should be emphasized. In previous studies, conflicting results were reported about the relationship between maternal education, paternal education, gender of the child, and screen time. ${ }^{26,27}$ Similar to Trinh and his colleagues, ${ }^{28}$ the present study demonstrated an inverse relationship between parental education level and screen time of children and also found that male gender was associated with increased screen time. In addition, Maatta et al., ${ }^{29}$ showed that parents with high education have lower descriptive norms, use fewer screens in front of children, and place greater importance on limiting children's screen time compared to parents with low education.

Findings related to maternal occupation, presence of siblings and the child's screen time differed in past studies. ${ }^{28}$ Hinkley et al., ${ }^{30}$ identified no association between maternal employment, the presence of siblings, and screen time for preschool children. On the contrary, Wu et al., ${ }^{31}$ reported that screening devices were used more frequently in children whose mothers were housewives compared to working mothers. Accordingly, in a prior study, children receiving home care are found to be more likely to be exposed to television than children who receive care at nurseries. ${ }^{32}$ In this study, mothers being a housewife and the presence of sibling were found to be positive determinants on screen time. It was also shown that the screen time of children cared at nurseries was significantly lower. The presence of siblings may increase the workload of the mother and decrease the quality time that the child spends with the mother, causing the screen time to increase at home care. Another reason may be that siblings are role models in terms of screen contact.

The strength of the study is that it is the first study to examine the associations of ER and children's excessive-screen time in preschool period with a standardized scale. There are also some limitations to be taken into account in our study. First, screen time was reported by mothers, and this may result in underestimates of screen time. However, mothers are expected to have an idea about the ideal screen time to take sides when answering the questionnaire. In our study, it can be thought that the probability of bias decreases with the high ratio of mothers reporting that their children have screen time over 4 hours. Second, although participant mothers do not have diagnosed psychiatric diseases, their psychological well-being can be a confounding factor. This should be taken into consideration in further studies. Third, the total length of stay in the nursery was not questioned in hours. Nevertheless, regardless of the duration of their stay in the nursery, the fact that the child attended the nursery was associated with low screen time. 


\section{CONCLUSIONS}

This study investigating the relationship between the emotion regulation skill and screen time revealed that excessive screen time is associated with emotional lability in this early childhood period.

\section{REFERENCES}

1. Sevcikova A. Two sides of the same coin: communication technology, media use, and our kids' health. Int J Public Health. 2015; 60(2):129-30.

2. Radesky JS, Schumacher J, Zuckerman B. Mobile and interactive media use by young children: the good, the bad, and the unknown. Pediatrics. 2015; 135(1):1-3.

3. Council on Communications and Media. Media and young minds. Pediatrics. 2016; 138(5):e20162591.

4. American Academy of Child \& Adolescent Psychiatry. Media Habits During COVID-19: Children \& Teens on Screens in Quarantine. AACAP. 2020. [Accessed on: Sept 14, 2020]. Available in: https://www.aacap.org/App_ Themes / AACAP / Docs / resource_libraries / covid-19/ Screen-Time-During-COVID.pdf

5. Kostyrka-Allchorne K, Cooper NR, Simpson A. The relationship between television exposure and children's cognition and behaviour: A systematic review. Dev Rev. 2017; 44:19-58.

6. Lissak G. Adverse physiological and psychological effects of screen time on children and adolescents: literature review and case study. Environ Res. 2018; 164:149-57.

7. Schmidt ME, Rich M, Rifas-Shiman SL, Oken E, et al. Television viewing in infancy and child cognition at 3 years of age in a US cohort. Pediatrics. 2009; 123(3):e370-5.

8. Linebarger DL, Vaala SE. Screen media and language development in infants and toddlers: An ecological perspective. Dev Rev. 2010; 30(2):176-202.

9. Thompson R. Emotion regulation: a theme in search of a definition. In: Fox NA, ed. Emotion Regulation: Biological and Behavioral Considerations. Monographs of the Society for Research in Child Development. Chicago: University of Chicago Press; 1994; 59:25-52.

10. Roque L, Verissimo M, Fernandes M, Rebelo A. Emotion regulation and attachment: Relationships with children's secure base, during different situational and social contexts in naturalistic settings. Infant Behav Dev. 2013;36(3):298-306.

11. Garber J, DodgeKA. Cambridgestudies in social and emotional development. The development of emotion regulation and dysregulation. Cambridge: University Press; 1991.

12. Akçay D, ÖzcebeH. Evaluation of Computer Game Playing Habits of Children at Pre-School Education Levels and Their Families. J Child. 2012; 12:66-71.

13. YalçınS, Yıldız YahşiD, Oflu A, TezolÖ, atal.Multi-centered investigation of pre-school children's screen time and digital game playing habits. Fulltext paper. International Child and Information Safety Congress "Digital Games". April 11-13, 2018. Ankara.

14. Waisman I, Hidalgo E, Rossi ML. Uso de pantallas en niños pequeños en una ciudad de Argentina. Arch Argent Pediatr. 2018; 116(2):186-95.
15. Shields A, Cicchetti D. Emotion regulation among schoolage children: The development and validation of a new criterion Q-sort scale. Dev Psychol. 1997; 33(6):906-16.

16. Batum P, Yağmurlu B. What counts in externalizing behaviors? The contributions of emotion and behavior regulation. Curr Psychol. 2007; 25:272-94.

17. Ergüney M. İnternetin Okul Öncesi Dönemdeki Çocuklar Üzerindeki Etkileri Hakkında Bir Araştırma. Ulakbilge. 2017; 5(17):1917-38.

18. Skalická V, Wold Hygen B, Stenseng F, Kårstad SB, et al. Screen time and the development of emotion understanding from age 4 to age 8: A community study. Br J Dev Psychol. $2019 ; 37: 427-43$.

19. Kim-Spoon J, Cicchetti D, Rogosch FA. A longitudinal study of emotion regulation, emotion lability-negativity, and internalizing symptomatology in maltreated and nonmaltreated children. Child Dev. 2013; 84(2):512-27.

20. Eisenberg N, Fabes RA, Murphy B, MaszkP, etal. The role of emotionality and regulation in children's social functioning: A longitudinal study. Child Dev. 1995; 66(5):1360-84.

21. Kim J, Deater-Deckard K. Dynamic changes in anger linking to developmental trajectories of internalizing and externalizing problems: The moderating role of attention. J Child Psychol Psychiatry. 2011;52(2):156-66.

22. Neophytou E, Manwell L, Eikelboom R. Effects of Excessive Screen Time on Neurodevelopment, Learning, Memory, Mental Health, and Neurodegeneration: a Scoping Review. Int J Ment Health Addict. 2019; [In Press].

23. Canadian Paediatric Society, Digital Health Task Force, Ottawa, Ontario. Screen time and young children: Promoting health and development in a digital world. Paediatr Child Health. 2018; 23(1):83.

24. Przybylski AK, Weinstein N. Digital screen time limits and young children's psychological well-being: Evidence from a population-based study. Child Dev. 2019; 90(1):e56-65.

25. Twenge JM, Campbell WK. Associations between screen time and lower psychological well-being among children and adolescents: Evidence from a population-based study. Prev Med Rep. 2018; 12:271-83.

26. Duch H, Fisher EM, Ensari I, Harrington A. Screen time use in children under 3 years old: a systematic review of correlates. Int J Behav Nutr Phys Act. 2013; 10:102.

27. Carson V, Janssen I. Associations between factors within the home setting and screen time among children aged 0-5 years: a cross-sectional study. BMC Public Health. 2012; 12:539.

28. Trinh MH, Sundaram R, Robinson SL, Lin TC, et al. Association of Trajectory and Covariates of Children's Screen Media Time. JAMA Pediatr. 2019; 174(1):71-8.

29. Määttä S, Kaukonen R, Vepsäläinen $H$, Lehto E, et al. The mediating role of the home environment in relation to parental educational level and preschool children's screen time: a cross-sectional study. BMC public health. 2017; 17(1):688.

30. Hinkley T, Salmon J, Okely AD, Trost SG. Correlates of sedentary behaviours in preschool children: a review. Int J Behav Nutr Phys Act. 2010; 7:66.

31. Wu CST, Fowler C, Lam WYY, Wong HT, et al. Parenting approaches and digital technology use of preschool age 
children in a Chinese community. Ital J Pediatr. 2014; 40:44. 32. Christakis DA, Garrison MM. Preschool-aged children's television viewing in child care settings. Pediatrics. 2009; 124(6):1627-32. 